\title{
Contrastant banana accessions for resistance to the burrowing nematode, based on molecular markers RAPD
}

\author{
J. R. P. Santos $\cdot$ M. A. Teixeira $\cdot$ J. E. Cares \\ F. G. Faleiro · D. C. Costa
}

Received: 3 March 2009/ Accepted: 1 July 2009/Published online: 18 July 2009

(C) Springer Science+Business Media B.V. 2009

\begin{abstract}
This work aimed to proceed molecular characterization of seven banana accessions (Borneo, Grand Naine, 1304-06, 4249-05, 0337-02, 0323-03 and 4279-06) resistance to the nematode Radopholus similis. These accessions were selected taking in account the reproduction factor (RF) among 26 banana genotypes from a working collection belonging to Embrapa Mandioca e Fruticultura Tropical.
\end{abstract}

Part of the Master Dissertation of senior author at the University of Brasilia, with financial support of $\mathrm{CNPq}$ (Brazilian Council for Scientific and Techological Development).

J. R. P. Santos · M. A. Teixeira · J. E. Cares ( $\square)$

Dep. de Fitopatologia, Instituto de Ciências Biológicas, Universidade de Brasília (UnB), Caixa Postal 4457, Brasília, DF 70910-900, Brazil

e-mail: cares@unb.br

J. R. P. Santos

e-mail: jansen@unb.br

M. A. Teixeira

e-mail: marcella@unb.br

F. G. Faleiro

Embrapa Cerrados, BR 020, Km 18, Caixa Postal 08223,

Planaltina, DF 73010-970, Brazil

e-mail: ffaleiro@cpac.embrapa.br

D. C. Costa

Embrapa Recursos Genéticos e Biotecnologia, Caixa

Postal 02372, Brasília, DF 70849-970, Brazil

e-mail: dilson@cenargen.embrapa.br
The genomic DNA of the seven accessions was extracted, and 36 decamere primers had been used to obtain RAPD markers. The resulting markers were converted into a matrix of binary data. From that matrix the genetic distance between the accessions were estimated, for further clustering and graphic dispersion analyses. From a total of 521 RAPD markers generated, $420(81 \%)$ were polymorphic, including $140(27 \%)$ potentially promising for application on works related to genetic mapping of the resistance to $R$. similis. OPE-15, OPH-17, and OPG09 were the primers that contributed to the highest number of bands promising for genetic mapping of resistance $(12,8$, and 8 , respectively). The genetic distances between accessions ranged from 0.106 to 0.455 , with the longest one observed between $\mathrm{cv}$. Borneo and the genotype 4279-06, considered as highly susceptible and resistant, respectively, to the nematode according to the RF. The graphic dispersion distinguished three groups of accessions, and most of resistant genotypes clustered together in the same group. The most contrastant genotypes for resistance (Borneo and 4249-05) were separated by a genetic distance of 0.374 , and possessed a total of 114 polymorphic bands promising for genetic mapping of resistance. In addition, the results of pathogenicity tests were congruent with those obtained by RAPD analyses.

Keywords Genetic diversity - Musa . Molecular marker $\cdot$ Radopholus similis 


\section{Introduction}

Banana is among the most popular fruits worldwide, and it is grown in the majority of the tropical countries. Brazil ranks as second place in world banana production, although near to $100 \%$ of fruit production is destined to the domestic market, where the preference is for cultivars in the group $\mathrm{AAB}$, subgroup "Prata".

Banana plant is suitable host for important species of plant-parasitic nematodes, such as the burrowing nematode, Radopholus similis (Cobb 1893) Thorne, 1949; the spiral nematode, Helicotylenchus multicinctus (Cobb 1893) Golden, 1956; the lesion nematode, Pratylenchus coffeae (Zimmermann 1898) Filipjev and Schuurmans Stekhoven, 1941; the rootknot nematode, Meloidogyne spp., and the reniform nematode, Rotylenchulus reniformis Linford and Oliveira, 1940. Especially, $R$. similis, H. multicinctus, $P$. coffeae and Meloidogyne spp. are limiting factors in various banana growing areas due to difficult and onerous nematode control.

The use of plant resistance has been proved to be an efficient and low cost method of disease control. Therefore, the possibility of using genetic resistance to control plant-parasitic nematodes in bananas has been explored by several authors (Fogain and Gowen 1997; Costa et al. 1998; Marin et al. 1998; Elsen et al. 2002; Vilas Boas et al. 2002; Costa 2004). Search for resistance to plant-parasitic nematodes is dependent on the genetic variability of the host, as well as, on the genetic variability among nematode populations. The genetic basis for banana resistance to $R$. similis remains to be understood, although there is evidence that the resistance is controlled by one or more dominant genes (Pinochet 1988). For banana breeding programs is of capital importance to understand the kind of resistance and the mechanisms of nematode resistance in resistant accessions of bananas (Giebel 1982). The accomplishment of these studies needs a strong support from works planned to determine the degree of resistance or tolerance to the pathogen, and from studies based on molecular markers applicable on characterization and evaluation of genetic variability in bananas (Bhat and Jarret 1995; Pillay et al. 2000).

The advent of techniques possible to detect polymorphisms at DNA level has generated a large number of molecular markers for genetic testing and fingerprinting of individuals (Jeffreys et al. 1985). Molecular markers were used in the characterization and assessment of genetic variability in Musa, including RFLP (Restriction Fragment Length Polymorphism) (Fauré et al. 1994), RAPD (Random Amplified Polymorphic DNA) (Bhat and Jarret 1995; Pillay et al. 2000; Sawazaki et al. 2002); AFLP (Amplified Fragment Length Polymorphism) (Loh et al. 2000) and microssatelites or SSRs (Simple Sequence Repeats) (Kaemmer et al. 1997; Crouch et al. 1998; Grapin et al. 1998; Lagoda et al. 1998; Creste et al. 2001, 2003; Bonamico et al. 2004).

Bhat and Jarret (1995) demonstrated the application of RAPD markers on the characterization of germplasm of Musa spp., and it has been possible to distinguish clones that were morphologically identical.

Jesus et al. (2006) working with the techniques of microsatellite and RAPD obtained similar responses with the two techniques, for the separation of genotypes according to the genomic group and origin of hybrids. This shows that the technique of RAPD has considerable reliability, since it repeats results generated by other techniques. This fact justifies the use of RAPD technique to obtain markers that can lead to the mapping of resistance genes. Furthermore, for the required saturation of genetic maps it is interesting the use of different types of molecular markers, including RAPD.

The objective of this study was to use molecular markers RAPD, to carry out the molecular characterization of seven genotypes of Musa contrasting to the phenotypes of resistance to the nematode $R$. similis, aiming to identify promising primers and RAPD markers for upcoming studies on mapping of genetic resistance.

\section{Materials and methods}

The banana genotypes Borneo, Grand Naine, 130406, 4252-03, 8694-15, 1304-04, Pipit, 5854-03, 131801, 4285-02, N118, Tjau Lagada, Calcutta, 1319-01, Pa Rayong, Birmanie, Vitoria, Pisang Nangka, Thap Maeo, 4223-06, Jaran, Yangambi Km 5, 4279-06, 0323-03, 0337-02 and 4249-05, from the banana germplasm bank of Embrapa Mandioca e Fruticultura Tropical, were evaluated for reaction of susceptibility 
Table 1 Accession of banana analyzed expressing phenotype of resistance or susceptibility to Radopholus similis based on the reproduction factor

\begin{tabular}{llll}
\hline Number & Accession & Reproduction factor & Phenotype \\
\hline 1 & Borneo & 21.31 & HS \\
2 & Grand Naine & 11.30 & $\mathrm{~S}$ \\
3 & $1304-06$ & 11.00 & $\mathrm{~S}$ \\
4 & $4249-05$ & 0.01 & $\mathrm{HR}$ \\
5 & $0337-02$ & 0.11 & $\mathrm{R}$ \\
6 & $0323-03$ & 0.40 & $\mathrm{R}$ \\
7 & $4279-06$ & 0.41 & $\mathrm{R}$ \\
\hline
\end{tabular}

$H S$ highly susceptible, $S$ susceptible, $H R$ highly resistant, $R$ resistant

or resistance to $R$. similis, under greenhouse conditions, according to Santos (2007).

After evaluation of the reproduction factor of $R$. similis in the 26 accessions of banana under greenhouse, seven genotypes were selected contrasting in relation to susceptibility/resistance to the nematode (Table 1). The three genotypes more susceptible according to the reproduction factor were Borneo, Grand Naine and 1304-06, while the four genotypes with the lowest reproduction factor, indicating a phenotype of resistance, were 4279-06, 0323-03, 0337-02 and 4249-05.

Samples of genomic DNA of the seven banana accessions were extracted using the method of CTAB (Doyle and Doyle 1990) with modifications (Faleiro et al. 2003). After extraction, DNA concentration was estimated by spectrophotometry at 260 and $280 \mathrm{~nm}$ (Sambrook et al. 1989). The visual appearance of total genomic DNA bands separated by electrophoresis in gel of agarose $0.8 \%$ was used as an indicator of integrity and purity of the DNA extracted. After the quantification, all DNA samples were diluted to the concentration of $10 \mathrm{ng} / \mu \mathrm{L}$.

A total of 48 primers belonging to the kits OPD, OPE, OPF, OPG and OPH (Operon Technologies Inc., Alameda, CA) were tested. The reactions of amplification were performed in a total volume of $13 \mu \mathrm{L}$, containing $10 \mathrm{mM}$ Tris- $\mathrm{HCl}(\mathrm{pH} 8.3), 50 \mathrm{mM}$ $\mathrm{KCl}, 3 \mathrm{mM} \mathrm{MgCl} 2,100 \mathrm{mM}$ of each deoxyribonucleotide (dATP, dTTP, and dCTP, dGTP), $0.4 \mathrm{mM}$ of a primer (Operon Technologies Inc., Alameda, CA), a unit of the enzyme Taq polymerase, and $\sim 15 \mathrm{ng}$ DNA.
The amplifications were performed in thermocycler programmed for 40 cycles, each one consisting of the following sequence: $15 \mathrm{~s}$ at $94^{\circ} \mathrm{C}, 30 \mathrm{~s}$ at $35^{\circ} \mathrm{C}$ and $90 \mathrm{~s}$ at $72^{\circ} \mathrm{C}$. After the 40 cycles, there was a step of final extension of $6 \mathrm{~min}$ at $72^{\circ} \mathrm{C}$, finally, the temperature was reduced to $4^{\circ} \mathrm{C}$.

After amplification, were added to each sample, $3 \mu \mathrm{L}$ of a mixture of blue Bromophenol (0.25\%) and glycerol $(60 \%)$ in water. The samples were applied to agarose gel $(1.2 \%)$, stained with ethidium bromide $(0.2 \mathrm{mg} / \mathrm{mL})$, submerged in TBE buffer $(90 \mathrm{mM}$ Tris-borate, $1 \mathrm{mM}$ EDTA) to separate the microsatellite fragments. The electrophoretic separation was for about $4 \mathrm{~h}$, at $85 \mathrm{~V}$. At the end of the electrophoretic running, the gels were photographed under UV light.

The RAPD markers generated were converted into a matrix of binary data, from which were estimated genetic distances between each pair of accessions, based on the similarity coefficient of $\mathrm{Nei}$ and $\mathrm{Li}$ (1979) (Table 2).

The matrix of genetic distances was used for the clustering analysis to generate a dendrogram using the method UPGMA (Unweighted Pair Group Method with Arithmetic Mean) as a criterion for grouping, and for the graphical dispersion based on multidimensional scales using the method of principal coordinates.

\section{Results}

Among the 48 decamere primers tested, 36 were selected which generated sharp and polymorphic molecular markers. The 36 primers (Table 2) generated a total of 521 RAPD markers, making an average of 14.5 markers per primer. As an example, we can highlight the pattern of amplification generated by the primer OPE-16 (Fig. 1), being possible to see clearly the presence of polymorphic markers originated.

Among the primers used only two (OPH-04 and OPF-20) did not generate bands in resistant and absent in all susceptible genotypes. Therefore, $96 \%$ of primers generated at least one promising band for genetic mapping. The primers OPE-15, OPH-17 and OPG-09 were those that conferred a larger number of promising bands (12, 8 and 8 , respectively), standing out among the others (Table 2). 
Table 2 Primers selected to obtain the RAPD markers, and the respective numbers of bands polymorphic, monomorphic, and those promising for works on genetic mapping of resistance to the nematode Radopholus similis

\begin{tabular}{|c|c|c|c|c|}
\hline Primers & Sequence $5^{\prime} \rightarrow 3^{\prime}$ & $\begin{array}{l}\text { No. of } \\
\text { polymorphic } \\
\text { bands }\end{array}$ & $\begin{array}{l}\text { No. of } \\
\text { monomorphic } \\
\text { bands }\end{array}$ & $\begin{array}{l}\text { No. of } \\
\text { promising } \\
\text { bands }\end{array}$ \\
\hline OPE-18 & GGACTGCAGA & 6 & 6 & 1 \\
\hline OPF-08 & GGGATATCGG & 14 & 2 & 4 \\
\hline OPF-14 & TGCTGCAGGT & 4 & 6 & 1 \\
\hline OPG-05 & CTGAGACGGA & 15 & 1 & 3 \\
\hline OPG-09 & CTGACGTCAC & 17 & 1 & 8 \\
\hline OPH-04 & GGAAGTCGCC & 8 & 2 & 0 \\
\hline OPH-12 & ACGCGCATGT & 14 & 3 & 2 \\
\hline OPH-17 & САСТСТССТС & 18 & 1 & 8 \\
\hline OPF-19 & СCTCTAGACC & 15 & 1 & 7 \\
\hline OPG-13 & СТCTCCGCCA & 6 & 4 & 2 \\
\hline OPD-11 & AGCGCCATTG & 9 & 2 & 1 \\
\hline OPH-02 & TCGGACGTGA & 11 & 0 & 4 \\
\hline OPG-18 & GGCTCATGTG & 9 & 1 & 1 \\
\hline OPH-06 & ACGCATCGCA & 7 & 2 & 1 \\
\hline OPH-08 & GAAACACCCC & 8 & 4 & 3 \\
\hline OPH-15 & AATGGCGCAG & 14 & 0 & 7 \\
\hline OPE-19 & ACGGCGTATG & 6 & 4 & 4 \\
\hline OPE-15 & ACGCACAACC & 19 & 0 & 12 \\
\hline OPE-16 & GGTGACTGTG & 15 & 4 & 6 \\
\hline OPE-17 & CTACTGCCGT & 4 & 4 & 2 \\
\hline OPF-03 & CCTGATCACC & 9 & 1 & 1 \\
\hline OPF-12 & ACGGTACCAG & 10 & 5 & 3 \\
\hline OPF-20 & GGTCTAGAGG & 9 & 3 & 0 \\
\hline OPG-08 & TCACGTCCAC & 10 & 6 & 2 \\
\hline OPE-07 & AGATGCAGCC & 12 & 2 & 7 \\
\hline OPG-12 & CAGCTCACGA & 14 & 6 & 4 \\
\hline OPG-17 & ACGACCGACA & 15 & 2 & 4 \\
\hline OPG-15 & ACTGGGACTC & 10 & 5 & 3 \\
\hline OPG-11 & TGCCCGTCGT & 16 & 3 & 5 \\
\hline OPE-09 & CTTCACCCGA & 12 & 3 & 4 \\
\hline OPE-05 & TCAGGGAGGT & 12 & 3 & 5 \\
\hline OPE-02 & GGTGCGGGAA & 11 & 4 & 5 \\
\hline OPE-11 & GAGTCTCAGG & 16 & 5 & 5 \\
\hline OPD-01 & ACCGCGAAGG & 18 & 1 & 7 \\
\hline OPD-02 & GGACCCAACC & 17 & 1 & 4 \\
\hline OPD-05 & TGAGCGGACA & 10 & 3 & 4 \\
\hline
\end{tabular}

Of the 521 markers, 101 (19\%) were monomorphic, $420(81 \%)$ were polymorphic and $140(27 \%)$ were promising for works on the genetic mapping of resistance to $R$. similis.

The genetic distances between accessions ranged between 0.106 and 0.455 (Table 3). The smallest genetic distance (0.106) was obtained between the genotypes 0337-02 and 4279-06, which reacted as resistant to the attack of the pathogen, followed by that observed among the genotypes Borneo and Grand Naine (0.287), which behaved as the most susceptible. The greatest genetic distance $(0.455)$ was 


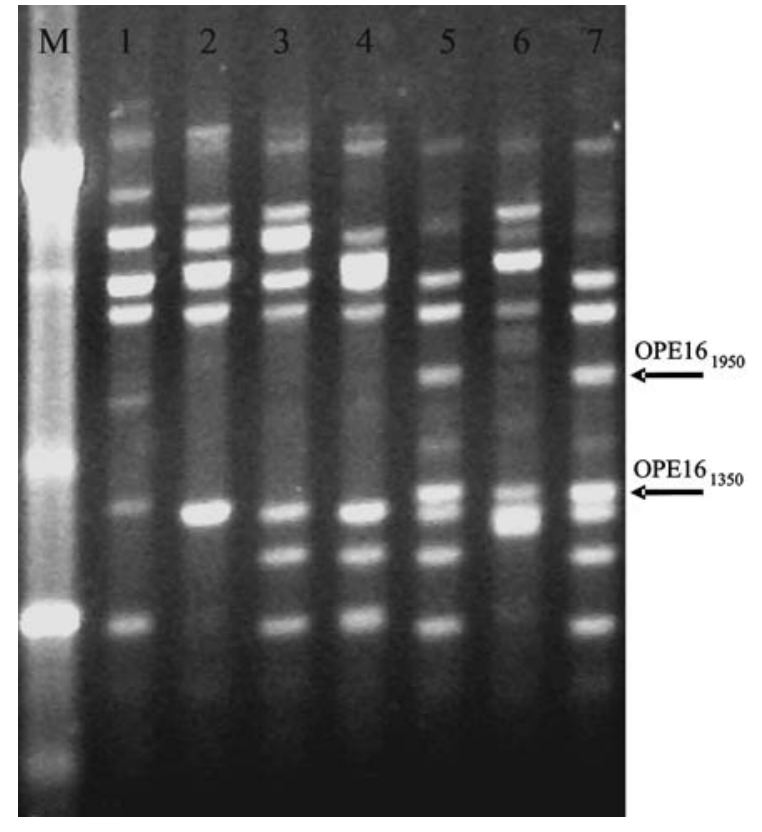

Fig. 1 Pattern of markers generated by the primer OPE-16 in the seven banana accessions. The markers indicated with arrows are promising for studies on genetic mapping. (M) Size markers (0.5-10 Kb); (1) Borneo; (2) Grand Naine; (3) 130406; (4) 4249-05; (5) 0337-02; (6) 0323-03; (7) 4279-06. (HS highly susceptible, $S$ susceptible, $H R$ highly resistant, $R$ resistant)

observed between cultivar Borneo and the genotype 4279-06, classified as highly susceptible and resistant, respectively.

The cluster analysis performed on the basis of genetic distances allowed to divide the seven accessions in at least three groups of genetic similarity to a relative genetic distance of 0.327 (Fig. 2). The distances between accessions and their distribution in groups of similarity can also be seen in the dispersion graphic (Fig. 3). The more contrasting accessions for resistance (Borneo and 4249-05) had a distance of 0.374 and a total of 114 polymorphic and promising bands for mapping (Tables 3, 4). The combination of Borneo with the resistant genotypes (4279-06, 0337-02 and 0323-03) also provided a high number of polymorphic bands (104, 111 and 106, respectively), as well as the intersection of 4279-06 with Borneo and 1304-06, and of these genotypes with 0323-03 (Table 4).

The analysis of dispersion based on genetic distances allowed the separation of most resistant accessions from the susceptible ones (Fig. 3).

\section{Discussion}

RAPD technique allowed to obtain large numbers of polymorphic markers, of which 140 appear to be promising for studies on genetic mapping of resistance to the nematode $R$. similis, i.e. were present in accessions resistant and absent in all susceptible accessions. The high average numbers of markers generated per primer and the low percentage of monomorphic markers demonstrate the high genetic variability among the accessions studied.

The high level of polymorphism, detected with the RAPD markers, is in agreement with that observed by Gomes et al. (2005). Jarret and Gawel (1995), using the technique of RAPD in the characterization of clones of plantains and the assessment of genetic diversity among diploids of $M$. acuminata, concluded that this technique can provide information on various aspects of genetic diversity in banana germplasm, such as the differentiation among clones morphologically identical.

The smallest genetic distance observed between the resistant genotypes 0337-02 and 4279-06, may be attributed to the fact the two diploid genotypes share Calcutta as common ascendant. The group consisting
Table 3 Matrix of genetic distances between seven accessions of banana susceptible and resistant to the nematode Radopholus similis, based on 521 RAPD markers

\begin{tabular}{llllllll}
\hline Genotypes & Borneo & G. Naine & $1304-06$ & $4249-05$ & $0337-02$ & $0323-03$ & $4249-06$ \\
\hline Borneo & 0 & & & & & & \\
G. Naine & 0.28712 & 0 & & & & & \\
1304-06 & 0.31168 & 0.32579 & 0 & & & & \\
$4249-05$ & 0.37369 & 0.31954 & 0.33595 & 0 & & & \\
$0337-02$ & 0.44034 & 0.37355 & 0.35080 & 0.36078 & 0 & \\
$0323-03$ & 0.45089 & 0.39903 & 0.39256 & 0.37074 & 0.31006 & 0 & \\
$4279-06$ & 0.45494 & 0.40758 & 0.38843 & 0.39271 & 0.10655 & 0.31049 & 0 \\
\hline
\end{tabular}




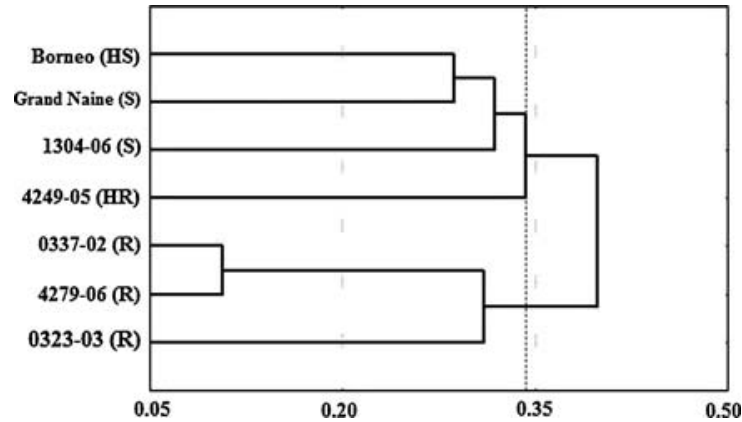

Fig. 2 Cluster analysis of seven accessions of banana based on the matrix of genetic distances calculated using 521 RAPD markers. The UPGMA method was used as a criterion for grouping. ( $H S$ highly susceptible, $S$ susceptible, $H R$ highly resistant, $R$ resistant)

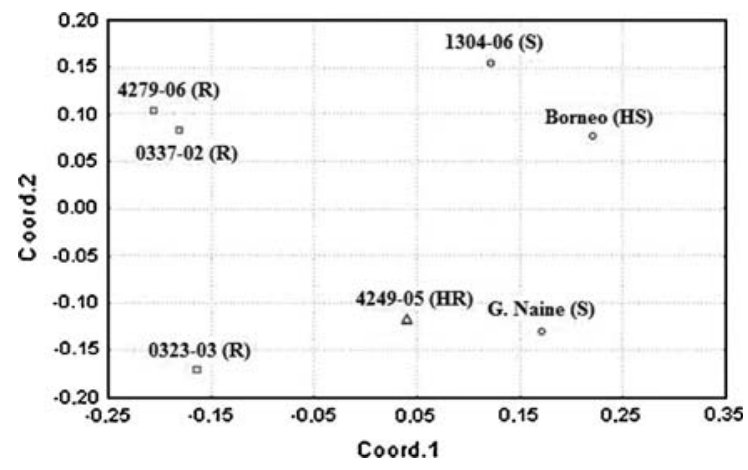

Fig. 3 Graphical dispersion of seven accessions of banana based on a matrix of genetic distances calculated using 521 RAPD markers. The matrix of genetic distances was displayed in a scatter plot based on the multidimensional scaling, using the principal coordinates analysis method. Accessions with the same symbol belong to the same group of similarity. (HS highly susceptible, $S$ susceptible, $H R$ highly resistant, $R$ resistant) of all resistant accessions, too is due to Calcutta, since this genotype is also an ascendant of 0323-03. The Diploid 4249-05 considered highly resistant, by the method UPGMA was closest to the susceptible accessions. Probably this genotype has part of its genetic material similar to that of the susceptible genotypes. This is an evidence that resistance to $R$. similis in banana can be determined by a few genes, as postulated by Pinochet (1988) that through preliminary studies demonstrated that resistance to $R$. similis can be controlled by one or more dominant genes.

The fact the more contrasting accessions for resistance (Borneo and 4249-05) have a total of 114 polymorphic and promising markers for genetic mapping, suggests that the crossing between these two genotypes could generate progenies of interest for understanding the inheritance of resistance to $R$. similis, and for future works on genetic mapping of resistance. The crossing of the diploid Borneo with any of the genotypes considered resistant (0337-02, 032303 or 4279-06) would also be of great importance, given the high number of promising markers found in these genotypes (111, 106 and 104, respectively).

Another promising analysis, would be that considering those markers observed in susceptible genotypes and absent in the resistant ones, where crosses between 4279-06 (resistant) and 1304-06 or Borneo (susceptible) could be made. Therefore, more accurate studies are necessary to determine the relationship between the markers and observed resistance genes in those plants, noting the occurrence of segregation of resistance in the crosses above indicated.

Table 4 Number of promising molecular markers for genetic mapping of pairing between resistant and susceptible accessions of banana to the nematode Radopholus similis

\begin{tabular}{|c|c|c|c|c|c|c|c|}
\hline Genotypes & Borneo & G. Naine & 1304-06 & 4249-05 & 0337-02 & 0323-03 & $4279-06$ \\
\hline Borneo & & & & 114 & 111 & 106 & 104 \\
\hline G. Naine & & & & 83 & 85 & 83 & 85 \\
\hline 1304-06 & & & & 95 & 81 & 87 & 80 \\
\hline 4249-05 & 65 & 56 & 76 & & & & \\
\hline 0337-02 & 92 & 76 & 93 & & & & \\
\hline 0323-03 & 96 & 83 & 103 & & & & \\
\hline 4279-06 & 103 & 87 & 108 & & & & \\
\hline
\end{tabular}

Values above diagonal are number of markers present in resistant genotypes and absent in susceptible ones and vice versa for values below diagonal 
The cluster analyzes by the method UPGMA and the graphical dispersion based on multidimensional scales using the principal coordinates, showed clearly the separation of banana genotypes contrastant for resistance to the nematode $R$. similis. The fact that these tools allow a distinct separation between the majority of the resistant and susceptible genotypes, indicates the existence of differences in the genetic background of those accessions. Also, these genetic differences open windows for future studies on genetic mapping of resistance of banana to the burrowing nematode.

\section{Conclusions}

The RAPD technique generates a large number of polymorphic markers between contrastant genotypes, which generate promising bands for genetic mapping of banana genotypes. By the analysis of dispersion is possible to separate the genotypes in groups, where resistant genotypes group with each other, as well as the most susceptible also group by themselves. The results of pathogenicity tests are congruent with the results obtained by the analysis of RAPD.

Acknowledgments To Dr. Sebastião de Oliveira e Silva, researcher of Embrapa Mandioca e Fruticultura Tropical, for kindly providing the accessions of bananas; to Graciella Belon, for invaluable laboratory help; to $\mathrm{CNPq}$ (The Brazilian Council for Scientific and Technological Development) for providing a scholarship for the first author during his Master Program at the University of Brasilia.

\section{References}

Bhat KV, Jarret RL (1995) Random amplified polymorphic DNA and genetic diversity in Indian Musa germplasm. Genet Resour Crop Evol 42:328-332

Bonamico N, Aiassa J, Ibañez M, Di Renzo M, Díaz D, Salerno J (2004) Caracterización y clasificación de híbridos simples de maíz con marcadores SSR. Rev Investig Agropecuarias 33:129-144

Costa DC (2004) Variabilidade patogênica e genética de Radopholus similis em bananeira no Brasil. Tese (Doutorado). Universidade de Brasília, Brasília

Costa DC, Silva SO, Alves FR (1998) Reação de genótipos de bananeira (Musa sp.) a Radopholus similis e Meloidogyne incognita. Nematol Bras 22:49-56

Creste S, Neto AT, Figueira A (2001) Detection of single sequence repeat polymorphisms in denaturing polyacrylamide sequencing gels by silver staining. Plant Mol Biol Rep 19:299-306
Creste S, Neto AT, Silva SO, Figueira A (2003) Genetic characterization of banana cultivars (Musa spp.) from Brazil using microsatellite markers. Euphytica 132(25):9-268

Crouch HK, Crouch JH, Jarret RL, Cregan PB, Ortiz R (1998) Segregation of microsatellite loci from haploid and diploid gametes in Musa. Crop Sci 38:211-217

Doyle JJ, Doyle JL (1990) Isolation of plant DNA from fresh tissue. Focus 12:13-15

Elsen A, Stoffelen R, Tuyet NT, Baimey H, Boulois HD, Waele D (2002) In vitro screening for resistance to Radopholus similis in Musa spp. Plant Sci 163:407-416

Faleiro FG, Faleiro ASG, Cordeiro MCR, Karia CT (2003) Metodologia para operacionalizar a extração de DNA de espécies nativas do cerrado. Embrapa Cerrados, Planaltina, p 6 (Comunicado Técnico No.92)

Fauré S, Noyer JL, Carreel F, Horry JP, Bakry F, Lanaud C (1994) Maternal inheritance of chloroplast genome and paternal inheritance of mitochondrial genome in banana (Musa acuminata). Curr Genet 25:265-269

Fogain R, Gowen SR (1997) Damage to roots of Musa cultivars by Radopholus similis with and without protection of nematicides. Nematropica 27:27-32

Giebel J (1982) Mechanisms of resistance to plant nematodes. Annu Rev Phytophathol 20:275-279

Gomes EWF, Willadino L, Martins LSS, Silva SO, Câmara TR (2005) Variabilidade genética de genótipos de bananeira (Musa spp) submetidos ao estresse salino. Rev Bras de Engenharia Agrícola e Ambiental 9:171-177

Grapin A, Noyer JL, Carreed F, Dambler D, Baurens FC, Lanaud C, Lagoda PJL (1998) Diploid Musa acuminata genetic diversity assayed with sequence tagged microssatellite sites. Electrophoresis 19:1374-1380

Jarret RL, Gawel N (1995) Molecular markers, genetic diversity and systematics in Musa. In: Gowen S (ed) Bananas and plantains. Chapman and Hall, London, pp 66-83

Jeffreys AJ, wilson V, Thein SL (1985) Hipervariable 'minisatellite' regions in human DNA. Nature 314:67-73

Jesus ON, Câmara TR, Ferreira CF, Silva SO, Pestana KN, Soares TL (2006) Diferenciação molecular de cultivares elites de bananeira. Pesqui Agropecu Bras 41:17391748

Kaemmer D, Fischer D, Jarret RL, Baurens FC, Grapin A, Dambier D, Noyer JL, Lanaud C, Kahl G, Lagoda PJL (1997) Molecular breeding in the genus Musa: a strong case for STMS marker technology. Euphytica 96:49-63

Lagoda PJL, Dambier D, Grapin A, Baurens FC, Lanaud C, Noyer JL (1998) Nonradioactive sequence tagged microsatellite site analyses: a method transferable to the tropics. Electrophoresis 19:152-157

Loh JP, Kiew R, Set O, Gan LH, Gan YY (2000) Amplified fragment length polymorphism (AFLP) fingerprinting of 16 banana cultivars (Musa spp.). Mol Phylogen Evol 17:360-366

Marin DH, Sutton TB, Barker KR (1998) Dissemination of bananas in Latin America and the Caribbean and its relationship to the occurrence of Radopholus similis. Plant Dis 82:964-974

Nei M, Li WH (1979) Mathematical model for studying genetic variation in terms of restriction endonucleases. Proc Natl Acad Sci 76:5269-5273 
Pillay M, Nwakanma DC, Teknouano A (2000) Identification of RAPD markers linked to A and B genome sequences in Musa L. Genome 43:763-767

Pinochet J (1988) Comments on the difficulty in breeding bananas and platains for resistance to nematodes. Rev Némalogie 11:3-5

Sambrook J, Fritsch EF, Maniats T (1989) Molecular cloning: a laboratory manual, 2nd edn. Cold Spring Harbor Laboratory, New York

Santos JRP (2007) Caracterização de genótipos de Musa com base na reação a Radopholus similis e de genótipos contrastantes para a resistência com base em marcadores moleculares RAPD. Dissertação (Mestrado), Universidade de Brasília, Brasília, p 72

Sawazaki HE, Barbosa W, Colombo CA (2002) Caracterização e identificação de cultivares e seleções de pereiras através de marcadores RAPD. Rev Bras Frutic 24:447-452

Vilas Boas LC, Tenente RCV, Gonzaga V, Neto SPS, Rocha HS (2002) Reação de clones de bananeira (Musa spp.) ao nematóide Meloidogyne incognita (Kofoid, White, 1919) Chitwood, 1949, Raça 2. Rev Bras Frutic 24:690-693 